Article

\title{
Pre-Service Teacher Preparedness for Fostering Education for Sustainable Development: An Empirical Analysis of Central Dimensions of Teaching Readiness
}

\author{
Loredana Manasia $₫$, Maria Gratiela Ianos * $*$ and Teodora Daniela Chicioreanu \\ Department of Teacher Education and Social Sciences, University POLITEHNICA of Bucharest, 313 Splaiul \\ Independentei, Sector 6, 060042 Bucharest, Romania; loredana.manasia@upb.ro (L.M.); \\ teodora.chicioreanu@upb.ro (T.D.C.) \\ * Correspondence: gratiela.ianos@upb.ro
}

Received: 31 October 2019; Accepted: 18 December 2019; Published: 24 December 2019

check for updates

\begin{abstract}
While it is generally agreed that teachers can shape student learning outcomes, there remains considerable debate on how national policies and training programmes can best support teacher education to address sustainable development challenges. This study aimed to develop a teaching readiness model with a focus on education for sustainable development. Therefore, the research investigated pre-service teachers' readiness for fostering education for sustainable development by applying its principles to teaching and learning activities. Pre-service teachers in science, technology, engineering, and mathematics responded to a survey regarding their perception of the readiness for designing, conducting, assessing, and engaging in teaching and learning experiences underpinning sustainable development. The results suggest professional knowledge and practice, professional engagement, and self-management could be considered central dimensions of teachers' job readiness, each of them encompassing a set of components or vectors. Moreover, professional knowledge has a strong and positive influence on teaching practice and professional engagement. In regard to professional knowledge, the ability to conduct didactic transposition is the most influential component. The most significant vectors of the professional practice dimension were found to be the ability to design effective evaluation tools and interpret learning outcomes. The research also revealed weak areas of teacher training: the ability to manage students' disruptive behaviors, to customize learning and to self-regulate teaching emotions.
\end{abstract}

Keywords: teaching readiness; teacher professionalism; teacher professional knowledge; teacher professional engagement; self-management; teacher professional practice; sustainable teacher education

\section{Introduction}

'Ensuring inclusive and equitable quality education and promoting lifelong learning opportunities for all' represents the fourth sustainable development goal on the United Nations' agenda. Achieving this goal requires complex endeavours and consistent interventions in various areas of education. In relation to this, teachers have a crucial role in shaping the potential of students to become agents of a sustainable future [1-3].

The transition to Education for Sustainable Development (ESD) is a frequently addressed topic in the recent literature [1,4-6]. Adopting innovative pedagogies in higher education has become one of the transition factors of ESD [7]. This transition also involves teachers who are motivated to act as agents of change [8] and to successfully fulfil the role of ESD teachers by adding value to education for sustainability $[2,9]$. 
One of the directions of action presented in the UNESCO report (2017) for the implementation of learning to achieve Sustainable Development Goals (SDGs) through ESD is integrating ESD in teacher education programmes [10].

In this paper, we focused on teacher education and readiness for teaching from an ESD perspective. We aimed to investigate the extent to which pre-service teachers (individuals who are enrolled in a teacher education programme that provides initial qualification, i.e., student teachers) perceive themselves ready for applying ESD principles to teaching and learning activities in science, technology, engineering, and mathematics (STEM).

In recent decades, education systems and various international profile organizations have sought solutions to provide the best answers to the challenges generated by the demands of the labour market, by the characteristics of the knowledge-based economy or even by the changes in the generation and individual profile of students. The ideas and solutions proposed are numerous and not necessarily convergent. Scholar experts have extensively voiced the need to invest in teacher education in order to increase their ability to effectively answer to various teaching situations [11,12]. Numerous and solid research studies have supported this recommendation, given that learning and its outcomes are dependent on the effectiveness of teaching [13,14]. Developing teacher professionalism as a strategic direction is a way to improve the quality of teaching and to improve teachers' perceptions of professional status, job satisfaction, and self-efficacy, contributing to a sustainable education [2].

The present paper reports on research into pre-service teachers' job readiness for teaching. In the following sections, we discuss theoretical approaches and structural components of the construct. Based on this analysis, a theoretical model is proposed in order to depict and interrelate the central dimensions of teaching readiness and their respective components.

\subsection{Context of the Study}

In several countries of the European Union, education systems are facing a shortage of teachers, especially in fields such as science, technology, engineering and mathematics [15]. The number of students who decide to enroll in teacher education programmes and the number of new teachers entering the teaching profession are among the key factors for a successful renewal of the teaching staff population [15]. However, their number is not the only challenge. In Romania, the low requirements for access to these programmes [15], added to the challenges of starting a teaching career, can be crucial factors in making the decision to enter the teaching profession. The perception of the state of readiness has proved itself to be a determining factor in the abandonment of the teaching profession [16]. Moreover, early-career teachers do not benefit from a period of supervised teaching. They are required to assume full responsibility from the very beginning of their career.

In Romania, initial teacher education offers two routes of certification. The first one is a 2-level parallel model meaning that education and training in specialism are combined with professional training for the teaching career within the same timeframe. Thus, undergraduate students can enroll for the teacher training programme of study (level 1) which takes three years. After successful certification, the graduates have access to teaching positions in lower secondary and upper secondary education (grades 9-10). The graduation of the first level is a prerequisite for the second level of training. The second level of certification can be achieved at the end of the master's studies and gives access to upper secondary and post-secondary nontertiary education.

Alternatively, there is a second route of certification for higher education graduates. They can follow a 2-semester teacher training programme (level 1 and level 2) and gain access into a teaching career in secondary and post-secondary nontertiary education. At present, the initial training for the teaching career of the secondary education personnel is provided by specialized structures within universities-Departments for Teacher Training (DPPD). Significant criticism has been formulated around the quality of teacher training in Romania.

The low level of training (especially practical training) offered through these initial training programmes is among the main problems highlighted in the education system in Romania [17]. 
The selection of candidates for the teaching profession through this exam and through the teacher licensing exam 'has proved to be less effective than having high entry standards and comprehensive initial teacher education' [15].

At the national level, various taxonomies of teacher competences have tried to lay the ground for common understanding and practice in initial teacher training [18]. Currently, three areas of competences are identified and applied in teacher appraisal: professional, psycho-pedagogical, and transversal $[17,18]$. Despite a vivid public and scientific debate, the national education system lacks a unified and coherent framework of teacher competences. Consequently, the quality of initial and continuous training could be widely affected $[15,19,20]$.

\subsection{Conceptual Framework}

\subsubsection{Teaching Readiness}

Despite the lively debate about young teachers' careers, very few studies have aimed at discussing more than an omnibus definition of the readiness for teaching concept. Mohamed et al. [12] (p. 153) defined readiness for teaching as the state of preparedness of student teachers for the teaching profession. Moreover, the authors suggested that a more specific approach to readiness would refer to an optimal level of professional competences development that would allow future teachers to assume job responsibilities in an effective way. Straková [21] (p. 33) argued that the readiness for teaching can be understood as 'the feeling of being ready for the job with the consideration of all aspects and elements which contributed to that feeling during pre-service training'. Park et al. [22] identified knowledge, attitudes and interests as specific elements of teaching readiness. In addition, these pillars are considered to be vectors of teaching efficacy. Fan et al. [23] narrowed the conception and pointed out knowledge about a specific subject matter and attitudes as components of teaching readiness. Moran and Hoy approached teacher's readiness as teacher efficacy, presenting a model (the Ohio State Teacher Efficacy Scale (OSTES) model), which includes three factors: instruction, management, and engagement. The study authors showed that 'Clearly, the strongest correlations between the OSTES and other measures are with scales that assess personal teaching efficacy' [24].

The study presented in this paper discusses the readiness for teaching from an ESD perspective. ESD proposes a framework for designing teaching and learning to empower people to take responsibility for creating and enjoying a sustainable future [25,26]. Moreover, ESD would prepare individuals of varying backgrounds to get ready for, to adapt to, and to solve complex problems of the modern and future world. Within this framework, five pillars could be unfolded, namely learning to know, learning to do and to be, learning to live together and to transform oneself and the society [27] (p. 8). In other words, the focus is to research whether pre-service teachers self-evaluate themselves as able of designing learning experiences to foster ESD and to empower pupils for sustainable development [28]. In order to do so, the five pillars have been operationalised in several transformative skills and attitudes that need to be addressed thorough instruction and learning [26].

Learning to know referred to skills such as critical thinking, problem solving, complex situation analysis, decision-making. Learning to do pointed to the ability to transfer learning outcomes to daily activities and life situations. Learning to live together implied communication and intercultural skills, teamwork and negotiation skills. Learning to be was translated into the following skills: setting goals, self-awareness, and self-management. As for the learning to transform oneself and the society pillar, it included abilities such as entrepreneurial mindset, innovation, idea generation, conflict solving.

\subsubsection{Teacher Professionalism}

Evans (2008) [29] stated that from a historical perspective, professionalism can be conceptualized as the junction between the level of autonomy and internal regulation demonstrated by employees in a specific field. The beginning of the 21st century has brought a change of perspective on the professionalisation of the teaching profession, which has become one of the directions of 
reform of the educational systems. This view is also supported by the conclusions of the World Education Forum in Dakar (2000) [30], that brought a reconfirmation of the international interest in promoting the professionalisation of the teaching profession by ensuring an adequate level of pay, access to professional development and participation in the process of making the decisions that influence the teaching career [31]. However, there are differences in understanding the concept of professionalism and how it can be operationalised at the level of different educational systems. Historical, cultural or political factors may be responsible for their occurrence and/or their perpetuation. Sexton [32] noted that there is not enough specialised literature to engage in a rigorous approach to defining the teaching profession. Moreover, the author noted that there are few sources trying to differentiate between the opinions expressed in the social space with regards to what this profession can represent. Continuing the conceptualisation approach, Sexton [32] emphasized that the idea of professionalism could be associated with the practitioner teacher, referring to the skills, attitudes, and practices that are necessary to the profession in order to provide services at a certain qualitative level.

This paper builds upon frameworks of teacher professionalism [31,33,34] and derives a model of pre-service teachers' readiness for the job, positing that readiness consists of four central dimensions: (1) professional knowledge, (2) professional practice, (3) professional engagement, and (4) self-management. Although the study aims to discuss the job readiness of pre-service teachers, the dimensions reviewed in the subsequent sections are not specific to pre-service teachers. Therefore, the available frameworks have been analysed and rephrased, resulting in 45 components that have been further clustered in four central dimensions.

\subsubsection{Professional Knowledge}

Wang et al. [33] define professional knowledge as a body of knowledge used in educational practice acquired through initial and continuous training, and through active participation in professional networks or working groups. This substrate is a central element of the teaching profession. Darling-Hammond [11] argued, based on evidence from empirical research and meta-analyses, that teachers who have benefited from training to stimulate their teaching skills show high self-confidence and succeed in developing positive and strong relationships with students. Moreover, studies have suggested that the number of years allocated to training for the teaching career influences the professionalism and performance of teachers [33].

$\operatorname{OECD}(2017,2018)$ highlights an evaluation framework with three common components of general pedagogical knowledge [35,36]: instructional process, learning process and assessment, each of them being associated with two sub-dimensions. In the same line of thoughts, the Australian Professional Standards for Teachers (AITSL) comprises three dimensions (professional knowledge, professional practice, and professional engagement) describing the key elements of teaching quality (what teachers should know and be able to do) through seven standards [37]. In England, the Professional Standards for Teachers and Trainers in Education and Training include 20 key elements grouped into three dimensions (professional values and attributes, professional knowledge and understanding, professional skills [38].

As Darling-Hammond suggests [19], teachers' professional knowledge requires a broad set of specialised knowledge of subject matter, pedagogy, and classroom management. Consistently, research studies have found that both subject matter and pedagogical knowledge can improve teachers' job performance [12,19,31]. Moreover, Darling-Hammond [19] emphasizes the variety and depth of pedagogical knowledge, by identifying specific types of knowledge (e.g., knowledge about learning and individual differences in learning; particularities of the socio-emotional, cognitive, moral, and physical development processes; and curricular design, instruction, and evaluation strategies).

Within the context of this study, the following types of knowledge have been retained: knowledge about learning, inter-individual differences in learning, and learning outcomes; didactic transposition and curriculum; knowledge about instructional strategies and learning activities design and the use of technologies to support instruction. 


\subsubsection{Professional Practice}

Teaching practice-as a dimension of teaching readiness-is mapped on the first three domains of the Danielson's Framework for teaching [34]. Danielson [34] associated teaching practice with 75 elements clustered into 22 components corresponding to four domains: planning and preparation (domain 1), classroom environment (domain 2), instruction (domain 3), and professional responsibility (domain 4) [39]. The first domain refers to instructional design skills and involves didactic transposition of scientific contents, and instructional and evaluation strategies correlated with learning objectives. The second domain encompasses skills contributing to the creation of simulative learning environments. Finally, the third domain encapsulates the first mission of teachers-instruction [39].

In our study, teachers' professional practice represents the ability to translate their professional knowledge into practice. More specifically, it refers to setting goals and objectives, designing effective instructional strategies, designing evaluation and assessment tools, the use of feedback functions, creating simulative learning environments that foster self-regulated learning and meet the individual needs of students.

\subsubsection{Professional Engagement}

In a broad view, teaching engagement is a measure of the personal investment of a teacher in all aspects of school-related activities. Watt, Richardson, and Wilkins defined professional engagement through planned effort, planned persistence, professional development aspirations, and leadership aspirations [40]. Neves de Jesus and Lens [41] considered that the professional engagement of teachers is an indicator of teacher job-related motivation. Considering this, Sato and Haegel [42] argued that the dynamic of the professional engagement is positively changed by formal and informal networking. This view is consistent with the one proposed by Wang, Lai and Lo [33], who put forward peer networks as a hallmark of teacher professionalism. Moreover, this dimension comprises components proposed by Danielson [34] in her framework for teaching and depicts elements and components associated with a true practitioner: reflection, respect for values, ethical conduct, and receptivity to feedback from colleagues.

In the context of the present study, we understand teacher professional engagement as a pillar of professional learning required to support career development and teacher professionalism. This dimension extends beyond the classroom and focuses on reflection, service to school and society, networking, personal development, respect for values and ethical conduct.

\subsubsection{Self-Management}

There is an extensive corpus of scientific developments aiming at exploring the concept of self-management. As Toma [43] argues, the self-management theory sees teachers as proficient decision-makers. In order to do so, Runhaar et al. [44] pointed out three directions of action, namely, creating opportunities, enhancing one's visibility, and seeking advice. Thus, self-management refers to teachers showing proactivity with respect to their career. In the same line of action, active networking, seeking support and positioning oneself could contribute to effective self-management [44]. Aside from the actional perspective, the projective approach identifies self-management with the ability to set goals for professional learning, to design achievement strategies and manage time and effort accordingly [45]. The level of individual achievement is assessed through self-evaluation [45]. The study conducted by Ngang et al. (2014) showed that teachers recognise the importance of soft skills in the teaching profession, but at the same time feel insufficiently prepared in this regard [46].

In the current study, self-management is rooted in the project management practices and corresponds to the components in the fourth domain of Danielson's framework [34]. Consequently, the teacher becomes a manager of actions, activities, and school-related processes allocating time and other resources to achieve goals. An essential attribute is the reflexive approach, empowering self-regulation. 


\subsection{Towards a Theoretical Model of Teaching Readiness}

The theoretical model we propose (Figure 1) is rooted in the models developed by Wang, Lai and Lo [33] and Danielson [34], and encompasses four central dimensions and 45 discrete components: (1) professional knowledge, (2) professional practice, (3) professional engagement and (4) self-management. The four dimensions and their respective components represent the core of what different professionalism frameworks consider as key factors of effective teaching. While the model can be applied for measuring the level of job readiness of pre-service teachers, it could be used as a framework for assessing the readiness for integrating ESD principles in teaching and learning activities in STEM disciplines. In addition, the empirical validation of the model could contribute to the creation of sustainable career paths for teachers in the pre-university education system, also providing useful information for updating the Romanian standards for teachers developed in 1999 [47].

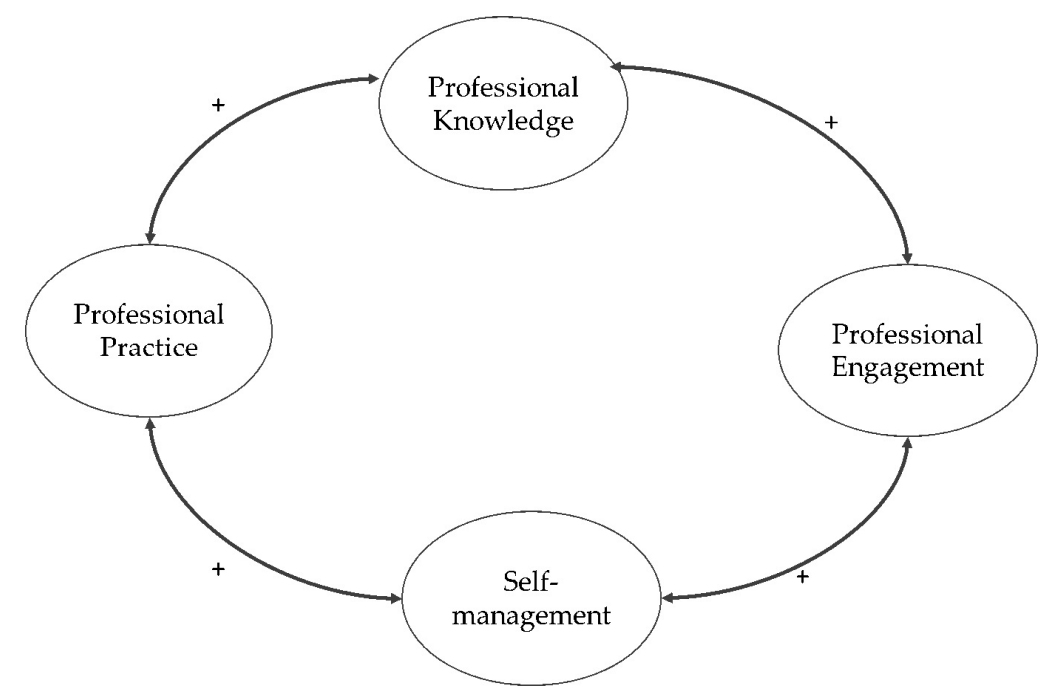

Figure 1. Teaching Readiness Model: Conceptualization of professional knowledge, professional practice, engagement and self-management.

The components corresponding to each dimension are presented below in full.

Professional knowledge (D1):

- D1_1 Knowledge of subject matter;

- D1_2 Knowledge of instructional strategies for critical thinking, problem solving, and decision making;

- D1_3 Knowledge of curricular documents;

- D1_4 Knowledge of didactical transposition techniques;

- D1_5 Knowledge of designing learning goals and objectives;

- D1_6 Knowledge of designing learning activities to foster transformative competences;

- D1_7 Knowledge of learning styles;

- D1_8 Knowledge of technology use in teaching and learning;

- D1_9 Knowledge of age-related differences in learning;

Professional practice (D2):

- D2_1 Setting learning goals to foster ESD pillars;

- D2_2 Instructional planning for sustainable development;

- D2_3 Designing learning activities considering age-related differences;

- D2_4 Applying different teaching strategies to help students to acquire life skills;

- D2_5 Integrating a wide range of resources into the teaching activity to engage students in their own learning process and to help them know themselves and others; 
- D2_6 Applying different communication techniques to foster collaborative learning;

- D2_7 Involving all students in learning activities;

- D2_8 Manage classroom activities and set clear rules;

- D2_9 Manage students' behavioural changes in order to help them self-regulate emotions and behaviours;

- D2_10 Contribute to students' safety within the school;

- D2_11 Use of technologies in a safe and responsible way;

- D2_12 Applying different evaluation strategies to assess both specific knowledge and skills, and transversal skills;

- D2_13 Designing effective assessment tools;

- D2_14 Providing feedback to stimulate learning to know and learning to learn abilities;

- D2_15 Interpretation of students' learning outcomes;

- D2_16 Communicating assessment results to improve student learning;

- D2_17 Supporting students' self-assessment to stimulate student agency;

Professional engagement (D3):

- D3_1 Effective self-assessment of training needs;

- D3_2 Commitment to professional development;

- D3_3 Ability to boost personal learning;

- D3_4 Selection of professionally relevant information;

- D3_5 Assuring learning to all students;

- D3_6: Seeking and receiving feedback from fellows;

- D3_7 Collaboration with parents and community members;

- D3_8 Commitment to ethical and professional aspects;

- D3_9 Commitment to national and institutional regulations;

- D3_10 Reflection and metacognition;

- D3_11 Commitment to the school's values;

- D3_12 Involvement in co-curricular activities to promote sustainable living;

Self-management (D4):

- Wellbeing and resilience;

- Management of personal activity;

- Emotional self-regulation;

- Time management;

- Self-motivation;

- Adaptability;

- Decision-making.

The model was empirically validated, and the following research questions were addressed:

1. Is the empirical data collected from pre-service STEM teachers in agreement with the proposed model?

2. Which are the most important indicators of professional knowledge, professional practice, professional engagement and self-engagement in the view of pre-service STEM teachers?

3. What sensitive indicators of professional knowledge, professional practice, professional engagement and self-engagement could be derived from the opinions of pre-service STEM teachers in relation to their readiness to teach for ESD?

This model postulates that the four latent variables (professional knowledge, professional engagement, professional practice, and self-management) are co-dependent and they have a strong 
and positive effect on each other. In addition, it has theoretical and practical implications as follows. Most previous papers have discussed the readiness for teaching from a more general perspective $[4,7,12,13,21]$ or have narrowed down the approach to a small set of teaching components or education levels (e.g., motivation, instructional strategies, and sustainability in primary education) $[2,6,22,23,42,46,48]$. In this paper, our focus was on a comprehensive approach of pre-service teachers' job readiness from an ESD perspective. Specifically, the components of the model addressed subjects' competency to actively integrate ESD principles into STEM activities. Therefore, the model identifies and operationalizes a relevant set of knowledge, skills, and dispositions that can be considered for designing and assessing teacher training programmes.

The approach we propose can also support the identification of sensitive areas that could eventually contribute to the improvement of initial teacher training. Moreover, empirical validation of the model would endorse the role of professional engagement and self-management in initial training in order to lay ground for professionalism and effectiveness in teaching.

Nevertheless, the study responds to calls for a better understanding of readiness for teaching in an Eastern European country. The model can represent a benchmark both at the managerial/ institutional level (for the management factors of the organizations directly involved in the development of these programmes) [49] as well as the instructional level (for the practitioners in the field, in an attempt to make the specific activities carried out within the training programmes' more efficient initially). "If the significant effects of teachers' beliefs in their capabilities were taken seriously, it could provoke significant changes in the way teachers were prepared and supported in their early years in the profession" [24].

\section{Materials and Methods}

\subsection{Research Design}

The current research study followed an exploratory empirical cross-sectional research design. Based on a quantitative approach, the study aimed to identify the central dimensions of teaching readiness from an ESD perspective.

Subsequently, the research revealed the extent to which the investigated pre-service teachers perceive themselves as prepared for the teaching profession.

\subsection{Participants and Sampling Design}

The reference population considered for selection of the sample consisted of pre-service STEM teachers. For sampling, a non-probability sampling strategy or criterion-sampling method was applied [50] (p. 267). Subsequently, the sample comprised student teachers who have completed their teaching practice.

The study group consisted of 312 undergraduate and postgraduate students from 15 faculties of the University POLITEHNICA of Bucharest, $73.7 \%$ of which were female and $26.3 \%$ male. The study of the literature has demonstrated that attracting men into the teaching profession is a real challenge [14] (p. 12). This aspect is also confirmed by the percentage of female teachers in the Romanian educational system: for example, in $2018,76.8 \%$ of the teachers in upper secondary education were female (age group 25-64 years) [51]. The participants were enrolled in bachelor's (77.2\%) and master's degree programmes $(22.8 \%)$ in STEM fields of study.

Descriptive information about the study group is presented in Table 1. 
Table 1. Demographic characteristics of respondents, $N=312$.

\begin{tabular}{cccc}
\hline Characteristic & Parameter & Frequency (N) & Percentage (\%) \\
\hline \multirow{2}{*}{ Gender } & Female & 230 & 73.7 \\
& Male & 82 & 26.3 \\
\hline \multirow{3}{*}{ Age (years) } & $<21$ & 2 & 0.6 \\
& $21-22$ & 228 & 73.1 \\
& $23-24$ & 73 & 23.4 \\
& $25-26$ & 5 & 1.6 \\
\hline \multirow{3}{*}{ Cycle of studies/Year of studies } & $>26$ & 4 & 77.2 \\
& 3rd/4th year of study & 241 & 22.8 \\
& 2 Master's degree, & 71 & \\
& 1st/2nd year of study & & \\
\hline
\end{tabular}

1 Teacher training programme, Level I. ${ }^{2}$ Teacher training programme, Level II. Source: Developed by the authors based on the collected data.

The subjects participated voluntarily in this study and their identity was kept confidential.

\subsection{Measurement Instrument}

A pre-tested self-administered questionnaire using a 5-point Likert scale was applied during the data collection process (Table A1). The questionnaire was designed by the authors to encompass the dimensions proposed by the theoretical model discussed in the first section of the paper and to address them from the perspective of the five pillars of ESD (learning to be, learning to know, learning to do, learning to live together and to transform oneself and society). The research instrument included three sections as follows. The first section addressed two filter items, followed by the socio-demographic section with five items (age, gender, field of study, year of study and cycle of study-bachelor's degree and master's degree). The third section contained 45 items associated with the four dimensions: D1 Professional Knowledge, D2 Professional Practice, D3 Professional engagement, and D4 Self-management. The items in the third section were assessed on a 5-point Likert scale in which $1=$ totally disagree, $2=$ disagree, $3=$ neither agree, nor disagree, $4=$ agree, $5=$ totally agree.

The questionnaire design followed a 3-stage process: (1) literature review and operationalisation of the theoretical model; (2) qualitative and quantitative pretesting of the initial version; (3) development of the final version. The first stage resulted in an initial version of the questionnaire where the four dimensions in the theoretical model have been operationalized and contextualized from the perspective of the ESD pillars. Thus, a comprehensive introduction to the questionnaire has been drafted in order to make it clear that the questionnaire assesses the readiness for teaching from the ESD perspective.

To pre-test the initial version a mixed approach blending qualitative and qualitative methods was applied. Two focus groups with undergraduate and postgraduate student teachers (a total number of 15 participants) have been organized. The participants read the questionnaire and the discussion was guided by the following criteria: the item clarity and difficulty, the evaluation scale, and the completeness of the questionnaire. Some of the participants suggested making a more direct reference to the ESD pillars in order to boost clarity. Therefore, there were items that have been reformulated based on participants' feedback. The improved version of the questionnaire was quantitatively pretested. The collected data were used to conduct reliability analyses.

The final version of the instrument has been self-administered to the selected sample of 312 respondents. Within the single construct scale of the questionnaire, Cronbach's alpha was calculated 'for indicating scale reliability, in the sense of the equivalence of items' [52]. The value obtained for Cronbach's alpha coefficient, $\alpha=0.973$, points to a very good scale reliability. In Table 2 , the Cronbach's alpha values calculated for each dimension are presented in detail. The lower values obtained for cases D1 and D4 are probably due to the smaller number of items associated with each dimension [53]. 
Table 2. Values of Cronbach's alpha coefficients.

\begin{tabular}{cc}
\hline Dimension & Cronbach's Alpha \\
\hline Questionnaire & $\alpha=0.973, \mathrm{~N}$ items $=45$ \\
D1 Professional knowledge & $\alpha=0.884, \mathrm{~N}$ items $=9$ \\
D2 Professional practice & $\alpha=0.939, \mathrm{~N}$ items $=17$ \\
D3 Professional engagement & $\alpha=0.925, \mathrm{~N}$ items $=12$ \\
D4 Self-management & $\alpha=0.882, \mathrm{~N}$ items $=7$ \\
\hline
\end{tabular}

Source: Developed by the authors based on the collected data.

\subsection{Data Collection Procedure}

The questionnaire was self-administered online at the end of the second semester of the academic year.

A total of 315 answers were collected, three of which were eliminated because two did not meet the elimination criterion and one did not mention the age.

\subsection{Data Analysis}

The data collected were analysed using IBM SPSS v25.0 (IBM, New York, NY, USA) and IBM Amos software v. 23.0) (IBM, New York, United States), and the analysis implied descriptive and inferential statistics and modelling through structural equation (SEM). The analyses were conducted in three stages as follows. The first stage consisted of conducting descriptive statistics in order to define the respondent's socio-demographic profile. The second stage consisted of conducting factor analysis to test the unidimensionality of the scales and to have a preliminary validation of the theoretical model. Finally, in the third stage, structural equation modelling was applied in order to confirm the adequacy of the model for the empirical data.

Principal Axis Factoring was applied in an exploratory manner to deduce the main factors described by the variables in the study and to reduce the data to a reasonable number of variables. Factor analysis was performed for each dimension included in the theoretical model. As discussed above, the Cronbach's alpha coefficient ranged from 0.882 to 0.973 , indicating a good to very good internal consistency of each dimension included in the model. The Kaiser-Meyer-Olkin measure of sampling adequacy was applied (usually recommended to be above the 0.6 value). The unidimensionality of the scales was also tested by the scree plot test and the Kaiser criterion-eigenvalues greater than 1 [54] (p. 280). In addition, Bartlett's test of sphericity was applied to test the adequacy of the data for factor analysis. Given that the coefficients satisfied the desirability conditions, for each dimension, a factor score was extracted using the regression method. The factor scores were used for further analyses.

By applying the factor analysis, we reduced the number of variables and tested the unidimensionality of each latent variable, but the analyses were separated, and the method was exploratory. Thus, structural equation modelling was applied to validate the results of the factor analysis and to test the hypotheses. Following the recommendations of Hooper, Coughlan, and Mullen [55], the normed/relative chi-square $\left(X^{2} / d f\right)$ could take values between 2 and 5 . Other fit indices were also computed and analysed: RMSEA, GFI, AGFI, RFI, and TLI. MacCallum, Browne and Sugawara [56] suggested that an RMSEA value between 0.05 and 0.10 can be considered a fair fit. More recent scholar opinions (e.g., Steiger) reported values less than 0.07 [57] in order to consider a correct fit of the model. Regarding the GFI, AGFI, CFI and TLI indices, the values should be close to the 0.95 threshold [55]. Values between 0.85 and 0.95 indicate a satisfactory fit of the model to empirical data [56]. In this paper, we followed the criteria and acceptable thresholds suggested by Hooper et al. [55] and MacCallum et al. [56].

\section{Results}

The present paper aimed at developing an explanatory model of pre-service teachers' readiness for teaching. The model includes a relevant selection of variables that can be encompassed in four 
dimensions: professional knowledge (variables D1_1 to D1_9), professional practice (variables D2_1 to D2_17), professional engagement (variables D3_1 to D3_12 and self-management (variables D4_1 to D4_7). Table 3 shows the means, standard deviations and skewness and kurtosis coefficients of the variables included in the model.

Table 3. Descriptive statistics of the variables included in the model.

\begin{tabular}{|c|c|c|c|c|c|}
\hline Variables & Range & Mean & Std. Deviation & Skewness & Kurtosis \\
\hline D1_1 & 4 & 4.37 & 0.77 & -1.43 & 2.85 \\
\hline D1_2 & 4 & 4.24 & 0.79 & -1.12 & 1.86 \\
\hline D1_3 & 4 & 4.26 & 0.84 & -1.30 & 2.26 \\
\hline D1_4 & 4 & 4.37 & 0.79 & -1.43 & 2.59 \\
\hline D1_5 & 4 & 4.53 & 0.72 & -1.90 & 4.96 \\
\hline D1_6 & 4 & 4.45 & 0.78 & -1.58 & 2.98 \\
\hline D1_7 & 4 & 4.03 & 0.86 & -0.52 & -0.35 \\
\hline D1_8 & 4 & 4.20 & 0.93 & -1.03 & 0.53 \\
\hline D1_9 & 4 & 4.07 & 0.88 & -0.62 & -0.16 \\
\hline D2_1 & 4 & 4.47 & 0.73 & -1.74 & 4.31 \\
\hline D2_2 & 4 & 4.31 & 0.82 & -1.37 & 2.44 \\
\hline D2_3 & 4 & 4.15 & 0.84 & -0.97 & 1.04 \\
\hline D2_4 & 4 & 4.28 & 0.80 & -1.18 & 1.83 \\
\hline D2_5 & 4 & 4.18 & 0.84 & -0.91 & 0.68 \\
\hline D2_6 & 4 & 4.33 & 0.81 & -1.36 & 2.50 \\
\hline D2_7 & 4 & 4.33 & 0.83 & -1.21 & 1.40 \\
\hline D2_8 & 4 & 4.37 & 0.80 & -1.45 & 2.58 \\
\hline D2_9 & 4 & 3.99 & 0.92 & -0.67 & 0.10 \\
\hline D2_10 & 4 & 4.29 & 0.89 & -1.49 & 2.59 \\
\hline D2_11 & 4 & 4.28 & 0.84 & -1.20 & 1.71 \\
\hline D2_12 & 4 & 4.25 & 0.78 & -0.96 & 1.08 \\
\hline D2_13 & 4 & 4.27 & 0.80 & -0.98 & 0.96 \\
\hline D2_14 & 4 & 4.41 & 0.81 & -1.66 & 3.36 \\
\hline D2_15 & 4 & 4.40 & 0.78 & -1.46 & 2.75 \\
\hline D2_16 & 4 & 4.46 & 0.72 & -1.33 & 1.87 \\
\hline D2_17 & 4 & 4.37 & 0.78 & -1.24 & 1.49 \\
\hline D3_1 & 4 & 4.23 & 0.80 & -1.05 & 1.51 \\
\hline D3_2 & 4 & 4.25 & 0.79 & -1.18 & 2.07 \\
\hline D3_3 & 4 & 4.39 & 0.79 & -1.44 & 2.63 \\
\hline D3_4 & 4 & 4.40 & 0.77 & -1.34 & 2.09 \\
\hline D3_5 & 4 & 4.50 & 0.76 & -1.95 & 5.03 \\
\hline D3_6 & 4 & 4.38 & 0.81 & -1.43 & 2.31 \\
\hline D3_7 & 4 & 4.17 & 0.93 & -1.16 & 1.34 \\
\hline D3_8 & 4 & 4.50 & 0.79 & -1.94 & 4.46 \\
\hline D3_9 & 4 & 4.44 & 0.83 & -1.80 & 3.81 \\
\hline D3_10 & 4 & 4.41 & 0.78 & -1.47 & 2.78 \\
\hline D3_11 & 4 & 4.47 & 0.79 & -1.93 & 4.89 \\
\hline D3_12 & 4 & 4.31 & 0.86 & -1.47 & 2.64 \\
\hline D4_1 & 4 & 4.49 & 0.80 & -1.83 & 3.90 \\
\hline D4_2 & 4 & 4.52 & 0.71 & -1.73 & 3.92 \\
\hline D4_3 & 4 & 4.16 & 0.88 & -1.09 & 1.26 \\
\hline D4_4 & 4 & 4.24 & 0.85 & -1.23 & 1.75 \\
\hline D4_5 & 4 & 4.43 & 0.80 & -1.74 & 3.77 \\
\hline D4_6 & 4 & 4.38 & 0.75 & -1.50 & 3.49 \\
\hline D4_7 & 4 & 4.41 & 0.80 & -1.51 & 2.64 \\
\hline
\end{tabular}

The mean analysis suggests that pre-service teachers scored highly on lesson planning and design (variables D1_5, D4_2, and D2_1), professional ethics (variables D3_8 and D3_11), and subjective happiness and wellbeing (variables D4_1). Classroom management and managing students' 
disruptive behaviour were sensitive aspects with the lowest scores (D2_9). In addition, providing customized learning could represent a weak aspect of pre-service teachers' readiness for teaching (variables D1_7, D1_9, and D2_3). The ability to self-regulate teaching emotions (D4_3) could be considered another sensitive aspect of a student teacher's job readiness, as the results suggest $\left(\right.$ Mean $_{D 4 \_} 3=4.16$, st. dev. $\left.=0.87\right)$. Mean differences between subgroups were tested by applying a one-way ANOVA test with Bonferroni correction. Significant differences in variables referring to lesson planning and design (D1_5, D4_2, D2_1) were found depending on respondents' age. Regarding the ability to define learning goals and objectives, the value was $F(4,307)=3.626, p=0.007$. A Bonferroni post hoc test revealed that pre-service teachers aged 25-26 years and above would score better in this ability $(p=0.005)$. We can assume that this is a result of gaining professional knowledge and practical experience through teaching practicum. No significant differences were found for the ability to self-regulate teaching emotions.

Garcia and Weiss [58] suggest that is very common for early career teachers to feel less that very well prepared when it comes to core activities underpinning the teaching activities (e.g., classroom management) due to the lack of a profound understanding of the profession.

As previously stated, principal axis factoring followed by Varimax rotation was applied to reduce the number of the variables and to test the unidimensionality of the four central dimensions in the theoretical model. There were 45 items included in the analyses. Table 4 shows items, communalities, item loadings, eigenvalues, KMO coefficients and the significance of the Bartlett's test for each of the four dimensions.

Table 4. Summary of factor analyses.

\begin{tabular}{|c|c|c|c|c|c|c|c|}
\hline Factor & Items & Communalities & Item Loading & $\%$ Variance Explained & Eigen Value & KMO & Bart. \\
\hline \multirow{9}{*}{$\begin{array}{l}\text { Professional } \\
\text { knowledge }\end{array}$} & D1_1 & 0.520 & 0.678 & \multirow[t]{9}{*}{52.764} & \multirow[t]{9}{*}{4.749} & \multirow[t]{9}{*}{0.913} & \multirow[t]{9}{*}{$p<0.01$} \\
\hline & D1_2 & 0.624 & 0.763 & & & & \\
\hline & D1_3 & 0.468 & 0.634 & & & & \\
\hline & D1_4 & 0.650 & 0.784 & & & & \\
\hline & D1_5 & 0.563 & 0.714 & & & & \\
\hline & D1_6 & 0.588 & 0.733 & & & & \\
\hline & D1_7 & 0.501 & 0.659 & & & & \\
\hline & D1_8 & 0.426 & 0.598 & & & & \\
\hline & D1_9 & 0.408 & 0.581 & & & & \\
\hline \multirow{17}{*}{$\begin{array}{l}\text { Professional } \\
\text { practice }\end{array}$} & D2_1 & 0.566 & 0.692 & \multirow[t]{17}{*}{51.136} & \multirow[t]{17}{*}{8.693} & \multirow[t]{17}{*}{0.946} & \multirow[t]{17}{*}{$p<0.01$} \\
\hline & D2_2 & 0.585 & 0.673 & & & & \\
\hline & D2_3 & 0.555 & 0.723 & & & & \\
\hline & D2_4 & 0.528 & 0.692 & & & & \\
\hline & D2_5 & 0.671 & 0.609 & & & & \\
\hline & D2_6 & 0.562 & 0.727 & & & & \\
\hline & D2_7 & 0.527 & 0.658 & & & & \\
\hline & D2_8 & 0.62 & 0.729 & & & & \\
\hline & D2_9 & 0.487 & 0.641 & & & & \\
\hline & D2_10 & 0.523 & 0.699 & & & & \\
\hline & D2_11 & 0.665 & 0.618 & & & & \\
\hline & D2_12 & 0.549 & 0.718 & & & & \\
\hline & D2_13 & 0.579 & 0.741 & & & & \\
\hline & D2_14 & 0.593 & 0.715 & & & & \\
\hline & D2_15 & 0.613 & 0.739 & & & & \\
\hline & D2_16 & 0.566 & 0.694 & & & & \\
\hline & D2_17 & 0.608 & 0.73 & & & & \\
\hline \multirow{12}{*}{$\begin{array}{l}\text { Professional } \\
\text { engagement }\end{array}$} & D3_1 & 0.456 & 0.639 & \multirow[t]{12}{*}{55.415} & \multirow[t]{12}{*}{6.650} & \multirow[t]{12}{*}{0.936} & \multirow[t]{12}{*}{$p<0.01$} \\
\hline & D3_2 & 0.539 & 0.704 & & & & \\
\hline & D3_3 & 0.588 & 0.742 & & & & \\
\hline & D3_4 & 0.562 & 0.722 & & & & \\
\hline & D3_5 & 0.622 & 0.768 & & & & \\
\hline & D3_6 & 0.520 & 0.69 & & & & \\
\hline & D3_7 & 0.501 & 0.675 & & & & \\
\hline & D3_8 & 0.619 & 0.767 & & & & \\
\hline & D3_9 & 0.596 & 0.749 & & & & \\
\hline & D3_10 & 0.603 & 0.754 & & & & \\
\hline & D3_11 & 0.581 & 0.737 & & & & \\
\hline & D3_12 & 0.463 & 0.644 & & & & \\
\hline
\end{tabular}


Table 4. Cont.

\begin{tabular}{|c|c|c|c|c|c|c|c|}
\hline Factor & Items & Communalities & Item Loading & $\%$ Variance Explained & Eigen Value & KMO & Bart. \\
\hline \multirow{7}{*}{ Self-management } & D4_1 & 0.603 & 0.733 & \multirow[t]{7}{*}{58.950} & \multirow[t]{7}{*}{4.126} & \multirow[t]{7}{*}{0.876} & \multirow[t]{7}{*}{$p<0.01$} \\
\hline & $\mathrm{D} 4 \_2$ & 0.607 & 0.736 & & & & \\
\hline & D4_3 & 0.512 & 0.656 & & & & \\
\hline & D4_4 & 0.626 & 0.752 & & & & \\
\hline & D4_5 & 0.598 & 0.729 & & & & \\
\hline & D4_6 & 0.560 & 0.696 & & & & \\
\hline & D4_7 & 0.621 & 0.748 & & & & \\
\hline
\end{tabular}

Source: Developed by the authors based on the collected data.

The KMO values were found to be between 0.876 and 0.946 , confirming the decision to conduct a factor analysis (see Table 4). The unidimensionality of the scales was also tested by the scree plot test and the Kaiser criterion-eigenvalues greater than 1 [54] (p. 280). Most of the extracted communalities $\left(h^{2}\right)$ were above $0.4\left(0.408 \leq h^{2} \leq 0.671\right)$. From a theoretical point of view, variables whose communalities are less than 0.4 should be eliminated from the analysis. However, these can be retained if they are theoretically relevant. At this point in the analysis, no variables were eliminated. In addition, the Bartlett's test of sphericity was applied to test the adequacy of the data to the factor analysis. The test was found to be statistically significant, $p<0.01$. Given the fact that the coefficients satisfied the desirability conditions, for each dimension a factor score was extracted using the regression method. The factor scores were used for further analyses.

In regard to the professional knowledge variable, the saturation coefficients indicate the ability to conduct didactic transposition (D1_4) as the most influential indicator. Following the same line of analysis, the most significant vectors of the professional practice variable are the ability to design effective evaluation tools and to analyse and interpret learning outcomes. In relation to professional engagement, the highest loadings were computed for the continuous professional development and training (0.76) and professional ethics (0.76). Finally, the self-management factor was influenced by the ability to manage time effectively (D4_4) and to make decisions (D4_7). From a practical perspective, it is relevant to underline that the lowest loading was computed for the item concerning emotional self-regulation $(0.65$, variable D4_3).

All the correlations between the four factor scores were medium to high in intensity $(r>0.6)$, positive, and statistically significant at the 0.01 level (see Table 5). The highest correlation score was computed between the professional engagement and self-management factor scores $(r=0.830, p=0.01)$. The second highest $r$ value was computed for professional knowledge and professional engagement factor scores $(r=0.757, p=0.01)$.

Table 5. Correlation matrix between factor scores, $N=312$.

\begin{tabular}{|c|c|c|c|c|}
\hline & Factor Scores & 1 & 2 & 3 \\
\hline 1 & Self_management & - & & \\
\hline 2 & Professional_engagement & $0.830^{* *}$ & - & \\
\hline 3 & Professional_practice & $0.706^{* *}$ & $0.731^{* *}$ & - \\
\hline 4 & Professional_knwoledge & 0.712 ** & $0.757^{* *}$ & $0.611^{* *}$ \\
\hline
\end{tabular}

The factor scores were also used to compare means between different subgroups depending on age, study domain, cycle of study and gender. In order to do so, one-way ANOVA with Bonferroni correction was applied.

As expected, significant differences were found between age segments for the self-management factor score: $F(4,307)=2.38, p=0.05$. The respondents aged $25-26$ years and above would be more effective in conducting self-regulatory activities. An important result was revealed for the professional engagement factor score: $F(4,307)=3.770, p=0.05$. Thus, the respondents aged below 25 years 
had higher means for professional engagement than the respondents aged above 25 years. The means for the professional engagement factor score decreased with age.

To confirm whether the empirical data is in agreement with the designed model, structural equation modelling was applied. Analysing the fit indices (Table 6), the model could be considered acceptable. The chi-square index $\left(\mathrm{CMIN}, \mathrm{X}^{2}\right)$ for model adequacy was not statistically significant $(p>0.01)$. The normed chi-square was 2.42 , being close to the lower threshold of 2 . The RFI index was lower than $0.8(R F I=0.76)$. The value of RMSEA was 0.064 , close to the value of 0.05 , which indicates a good match [56]. This means that these four factors can be treated as distinct latent variables.

Table 6. Goodness of fit indices of the initial readiness for teaching model, $N=312$.

\begin{tabular}{cccccccccc}
\hline & $\boldsymbol{X}^{2}$ & $\mathbf{D F}$ & $\boldsymbol{X}^{2} / \mathrm{DF}$ & $\boldsymbol{R M S E A}$ & GFI & AGFI & RFI & TLI & CFI \\
\hline $\begin{array}{c}\text { Initial model of } \\
\text { readiness for teaching }\end{array}$ & 2272.947 & 937 & 2.42 & 0.06 & 0.73 & 0.71 & 0.76 & 0.84 & 0.85 \\
\hline
\end{tabular}

Figure 2 presents the results of the SEM analysis in a visual form with standardized coefficients. The solidity of the four factors is reinforced by the high values of the communalities, most of them over 0.5 , and of the saturations (generally over 0.7 ). Moreover, the relations between the variables included in the model are consistent with the theoretical ground discussed in the first section of the paper, predicting covariances between latent variables. Thus, even though the model does not fit perfectly to empirical data, it offers a sound explanation of teaching readiness.

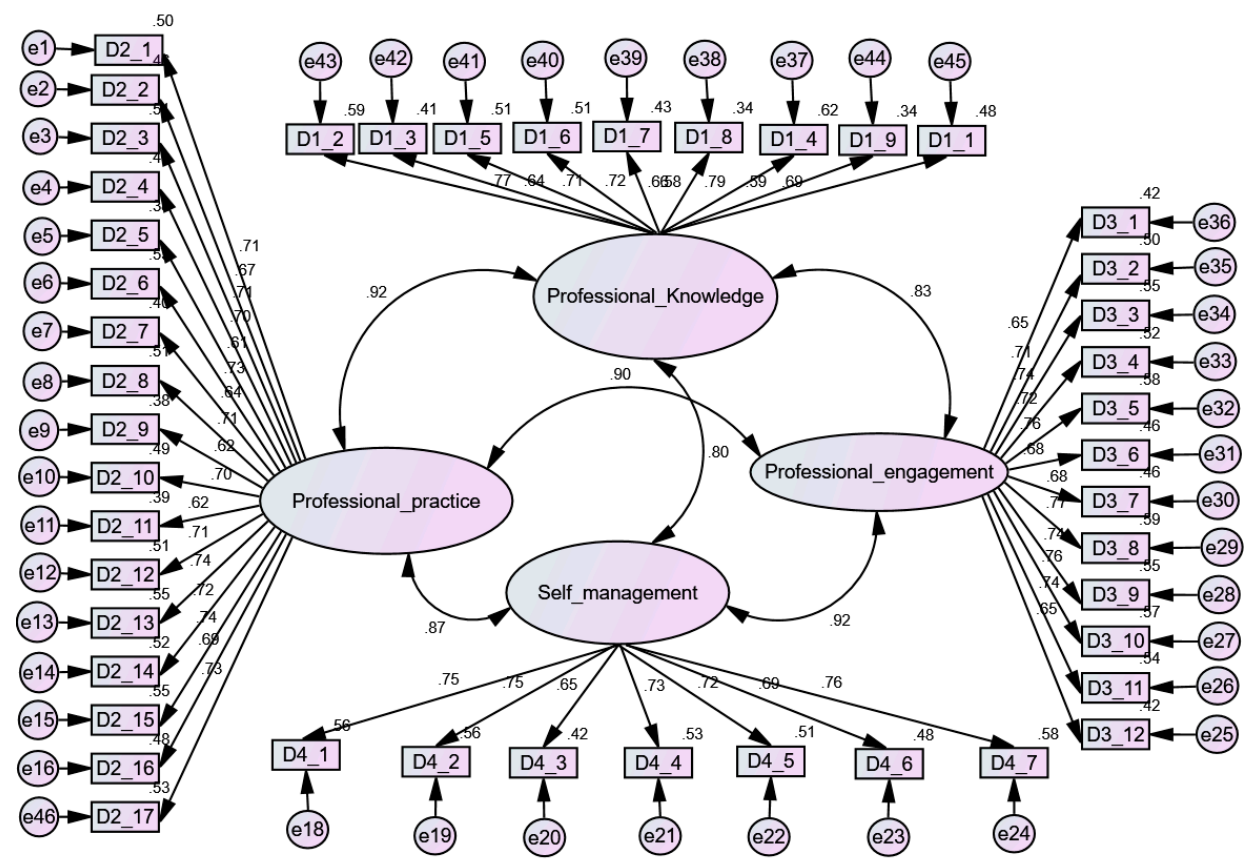

Figure 2. Structural equation initial model of pre-service teachers' readiness for teaching.

Usually, conducting an SEM analysis implies the testing of several variants to identify the model with the best characteristics [59-61]. In doing so, some variables and the relations between them were eliminated from the initial model. A significant change consisted of reducing the number of indicators of the latent professional knowledge, professional practice and professional engagement variables. The selection was based on the theoretical and statistical significance of the indicators. Therefore, in order to have more homogenous variables, the following indicators were removed based on the modification indices computed by Amos: D1_3, D2_1, D2_5, D2_6, D2_8, D2_9, D3_1, D3_3, D3_4, D3_8, D3_9.

The respecified model's fit indices are presented in Table 7, which shows that most fit indices (RMSEA, GFI, AGFI, RFI, TLI, CFI) improved in comparison with the initial model. 
Table 7. Goodness of fit indices of the refined teacher wellbeing model, $N=1092$.

\begin{tabular}{cccccccccc}
\hline & $\boldsymbol{X}^{2}$ & $\boldsymbol{D F}$ & $\boldsymbol{X}^{2} \boldsymbol{D} \boldsymbol{D F}$ & $\boldsymbol{R M S E A}$ & GFI & AGFI & $\boldsymbol{R F I}$ & $\boldsymbol{T L I}$ & CFI \\
\hline Refined Model & 1172.48 & 458 & 2.53 & 0.05 & 0.84 & 0.82 & 0.84 & 0.91 & 0.92 \\
Initial Model & 2272.947 & 937 & 2.42 & 0.06 & 0.73 & 0.71 & 0.76 & 0.84 & 0.85 \\
\hline
\end{tabular}

Source: Developed by the authors based on the collected data.

The teaching readiness and professionalism model proved a better fit to empirical data if some of the indicators referring to procedural knowledge on curriculum, learning objectives and disruptive behaviours were removed or treated as factual knowledge in the professional knowledge dimension. In addition, items referring to continuous development and self-actualisation needs were found to be more relevant in the self-management dimension. Therefore, the D3_1, D3_3 and D3_4 items were removed.

Figure 3 presents the refined model with the four latent variables (Professional_Knowledge, Professional_practice, Professional_engagement, and Self_management), observed variables and measurement error terms, standardised loading factors, and covariance coefficients.

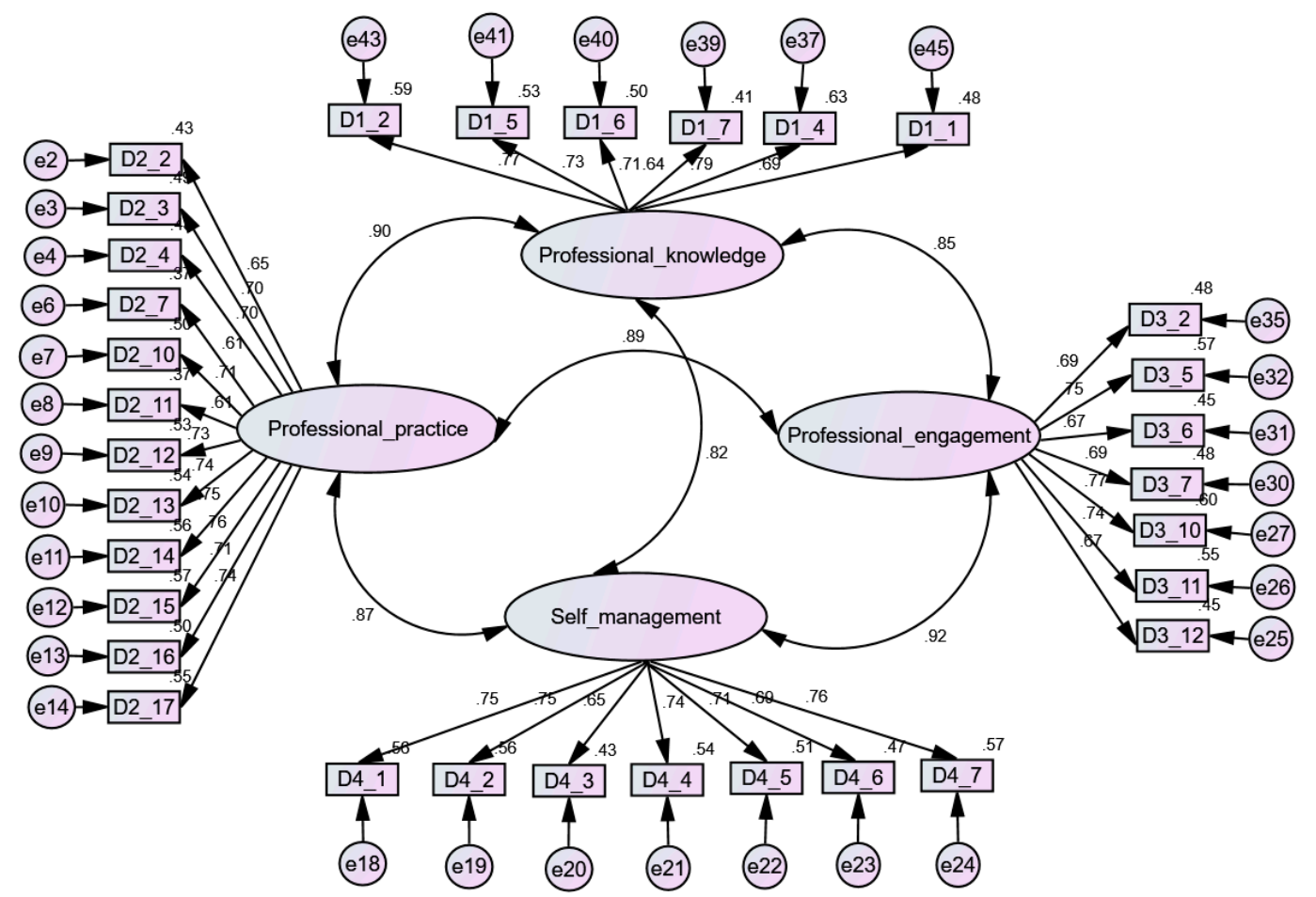

Figure 3. Structural equation refined model of pre-service teachers' readiness for teaching.

Finally, the correlation coefficients between the factors obtained through the SEM method with the correlations between factor scores calculated by Principal Axis Factoring Analysis were compared. Table 8 shows that the values obtained through SEM are, in all cases, higher than those obtained through $\mathrm{AF}$, but the order was preserved; thus, the model received an additional validation. All correlations are positive and statistically significant $(p<0.01)$. The strongest correlation between those estimated by the AMOS software is that between the professional engagement and self-management factors $(r=0.921)$. In other words, high levels of professional engagement will lead to a highly effective self-management and auto-efficacy. These results suggest that these variables covariate and influence one each other. 
Table 8. Latent variables' correlation coefficients computed through SEM and PCA methods.

\begin{tabular}{ccccc}
\hline \multicolumn{3}{c}{ Dimensions } & SEM & PCA \\
\hline Professional_engagement & $<->$ & Professional_Knowledge & 0.849 & 0.731 \\
Professional_engagement & $<->$ & Self_management & 0.921 & 0.830 \\
Professional_practice & $<->$ & Self_management & 0.874 & 0.706 \\
Professional_Knowledge & $<->$ & Professional_practice & 0.903 & 0.611 \\
Professional_engagement & $<->$ & Professional_practice & 0.889 & 0.731 \\
Professional_Knowledge & $<->$ & Self_management & 0.817 & 0.712 \\
\hline
\end{tabular}

Source: Developed by the authors based on the collected data.

As expected, between the professional knowledge and professional practice variables was a strong, positive, and statistically significant correlation: $r=0.903$. Therefore, a sound corpus of professional knowledge would significantly improve the teachers' capacity to make learning engaging and effective and to design challenging learning environments. In turn, professional practice would improve teachers' professional knowledge.

\section{Discussion}

This study aimed to investigate a theoretical model designed to assess the readiness for teaching of pre-service STEM teachers from an ESD perspective. In order to do so, a theoretical model echoing Danielson's framework [34] and Wang, Lai and Lo's model of professionalism [33] was designed. The respondents self-assessed their readiness for teaching by applying the instrument derived from the two evidence-based models [39]. Factor analysis and structural equation modeling proved that the empirical data were consistent with the designed model, offering a positive answer to the first research question. The four factors were co-dependent and influenced each other in a strong and positive way. Hence, high levels of professional knowledge are expected to impact all the dimensions of teachers' readiness for the job. In relation to professional knowledge, the focus is on pedagogical knowledge. The maximum importance given to it derives from quantitative and qualitative studies suggesting an association between teacher's level of pedagogical knowledge and the quality of student learning [62,63]. Additionally, studies have suggested that a well-articulated system of pedagogical knowledge facilitates effective teaching $[64,65]$. The values of the correlation coefficients calculated through the SEM analysis confirm the positive and significant effect of professional knowledge on professional practice $(r=0.903, p=0.01)$ and professional engagement $(r=0.849, p=0.01)$.

At the level of the professional engagement dimension, the ability to reflect on the teaching activity is the indicator with the highest item loading (0.77). Teaching requires time and deep reflection. Teachers constantly find themselves in contexts where they have to provide optimal answers to the demands of the educational environment and of the students. Expanding on the conceptualization proposed by Parsons, Davis, Scales, Williams and Kear [66], adaptive teaching can be defined as a teacher's succession of actions involving non-routine, proactivism and reinvention, leading to changes at the level of professional knowledge and practice. The adaptive capacity or adaptive expertise suggests a new possible perspective on the teaching profession, developed around the idea of uncertainty or newness [67]. Caena [68] proposed a tetradimensional model of adaptive capacity approach, which relates specialized knowledge, the ability to differentiate training, methodological knowledge and management of the student class, granted cross-sectionally with the ability to adapt the design and practice of teaching to the learning needs of the students. This new perspective emphasizes, once again, the relevance of professional knowledge in relation to professional practice and professional engagement. Within the professional engagement dimension, another important indicator is the concern for the participation in the continuous training of the teachers (factor loading $=0.75$ ). The participation in the training contributes to broadening the horizons of action and diversifies the portfolio of teaching staff practices. However, in the absence of favourable factors, the interest 
in applying new knowledge and skills in current contexts may fade. Professional development is necessary in the beginning phase of the teaching career and during it, but it is not a sufficient condition to ensure a high level of performance. In a UNICEF analysis [69], it is explained that professional development leads to improvement of professional performance, under optimal (self-)management conditions. Positive changes in performance (D2) lead to an increased level of responsibility (D3), which, in relation to various rewards, will echo the motivation and general well-being of the teacher (D4), thus ensuring the dynamics of all the factors involved. Narrowing the perspective, Romanian early-career teachers do not benefit from intensive and systematic support to ease the transition from teacher training programmes to effective practice. Translating scientific knowledge into learning activities, managing disruptive student behaviour or self-regulating teaching emotions need to be addressed in a more secure environment. Thus, actively supported mentoring activities and induction programmes are critical in developing a culture of learning schoolwide [58,70,71]. In view of boosting teacher professionalism and performance, scholar experts are voicing, at national level, the need to review the current practice in managing the teaching career. Expert groups have developed a more coherent model encompassing professional mentorship, formal preparation stages, and professional standards to regulate the teaching profession [72]. There are empirical studies suggesting that such a policy could be beneficial for teachers and students alike [58,70]. As other studies have pointed out, novice teachers are suffering from insufficient support for teacher learning, including inadequate peer support, challenging emotional experiences and a lack of teacher development programmes when they are on the job $[58,71]$.

As we argued before, the professional practice dimension refers to a teacher's primary mission, namely, that to design and deliver effective teaching. The OECD TALIS study [31] identified a number of elements that influence effective teaching: establishing an optimal learning environment, integrating learning scaffolding strategies, using collaborative and action training strategies, applying didactic transposition techniques meant to ensure accessibility and coherence of the taught educational content, assessment based on learning objectives and outcomes, explicit formulation of expectations regarding the students' learning activity. The values of the correlation coefficients calculated through the SEM analysis confirm that the nature of a teacher's knowledge can be seen as a practice mediated by social contexts and interactions [73]. In order to speed up the process of effectively translating into practice the professional knowledge, new teachers may need external professional support. Affiliation to professional networks and active membership to communities of practice have been proven to increase professional autonomy and self-efficacy $[19,31,70]$. Therefore, professional practice has a positive and statistically significant effect on all the other dimensions included in the projected model, professional knowledge $(r=0.903)$, self-management $(r=0.874)$ and professional engagement $(r=0.889)$.

The results show that, at the Professional Practice level (D2), the subjects feel the highest sensitivity (most sensitive areas). In decreasing order of this sensitivity, this is followed by Professional Engagement (D3), Self-Management (D4) and Professional Knowledge (D1).

Managing student behaviour changes (D2_9) seems to still be a challenge for teachers. It appears that this difficulty is not directly related to the experience gained [74], however, a more professional support/assistance supplemented by deeper knowledge of class management is believed to have an important role in the diminishment of these difficulties [75].

Not to be neglected is the sensitivity highlighted at the level of Self-Management (D4) concerning the efficient management of one's emotions during the activities (D4_3) and the efficient management of the time allocated to the activities (D4_4). Nevertheless, the difficulties regarding efficient time management in the classroom can be associated with inexperience, recent studies proving that they diminish as experience in the teaching profession is acquired [74].

The acquisition of certain self-management skills by the graduates contributes to the sustainability of the employment $[48,76]$. Although less investigated in studies regarding teacher readiness, the importance of self-management in the teaching profession should not be neglected. Thus, integrating this set of skills into initial teacher training would have considerable potential to improve 
the effectiveness of both teaching and learning as well as support the career development and enrichment processes [77]. The transfer of self-management skills to the workplace seems to be the most problematic type of transfer. This post-training transfer has been shown to be influenced by three categories of factors: "job-related factors, social support factors, and factors related to the organisational facilitation of learning" [78].

\section{Limitations of the Study}

The present study has several limitations. First, it is important to emphasize that the results and the conclusions cannot be generalised because of the sample and sampling design limitations. In this research, pre-university STEM teachers were sampled. Further research could consider a broader range of disciplines. Moreover, as explained in the introduction, two teacher certification paths are available in Romania. Although there are no differences in curriculum structure, the duration of studies varies significantly. Future research could also investigate whether the duration of initial training influences the perceived job readiness of pre-service teachers.

Secondly, the model designed in this study takes into consideration individual variables. In order to increase the adequacy of the model, external parameters could be considered (e.g., duration of the study programme). By doing so, mediation analysis could be conducted. In addition, further group differences could be explored in relation to gender, age, and field of study.

Thirdly, in this study we applied a cross-sectional design. A longitudinal design could be beneficial in terms of exploring the variations of job readiness under different circumstances. As stated before, ESD is not an explicit part of the teachers' initial training curriculum. Thus, investigating the effects of an ESD programme in a quasi-experimental design could focus more on the importance of ESD in teacher training.

\section{Conclusions}

The present paper aimed to develop and investigate a theoretical model to assess the job readiness of pre-service STEM teachers from an ESD perspective. In order to achieve this goal, the empirical validation of the model was sought by verifying that the theoretical model depicting four central dimensions (professional knowledge, professional practice, professional engagement and self-management) is consistent with empirical data. Moreover, the most important indicators and sensitive indicators of these central dimensions from the view of pre-service STEM teachers were identified.

The results show that the empirical data were in agreement with the model, offering a positive answer to the first research question and a sound explanation of teachers' readiness to foster ESD learning activities. The four factors are co-dependent and influence each other in a strong and positive way. The highest correlation score between the professional engagement and self-management factor and the second highest correlation for professional knowledge and professional engagement factor were found. The results emphasize the relevance of professional knowledge in relation to professional and professional engagement. On the other hand, professional practice has a positive effect on all the other dimensions included in the model. High levels of professional engagement will lead to a highly effective self-management and auto-efficacy.

Regarding the answer to the second question, in the view of pre-service STEM teachers, the most important indicators are lesson planning and design (variables D1_5, D4_2, D2_1), professional ethics (variables D3_8, D3_11), and subjective happiness and well-being (variables D4_1). The accumulation and deepening of professional knowledge as well as the practical experience through teaching practicum lead to the improvement of the lesson planning and design skills without significantly influencing the self-regulation capacity of teaching emotions.

Finally, managing students' disruptive behaviours (Professional Practice, D2), the customization of learning (Professional Knowledge, D1), management of relationships with parents (Professional 
Engagement, D3) and emotional self-regulation (Self-Management, D4) were evidenced as being the most sensitive/vulnerable areas of teaching readiness.

Despite the above-mentioned limitations, the study proposes a reliable model that can be used to assess the pre-service teachers' job readiness from an ESD perspective. Moreover, it includes personal variables, such as those included in the self-management dimension, that have been largely neglected in teacher training curriculum design. The direct implications and applicability of the study make it relevant for policy makers, school leaders, and practitioners in the field of teacher education.

Author Contributions: Conceptualization: M.G.I., L.M.; methodology: M.G.I., L.M.; validation: M.G.I., L.M.; formal analysis: M.G.I., L.M., T.D.C.; data collection: M.G.I., T.D.C.; investigations: M.G.I., L.M., T.D.C.; resources: M.G.I.; data curation: M.G.I., L.M.; T.D.C.; writing-Original draft preparation: M.G.I., L.M.; writing-Review and editing: Ianos M.G.I., L.M.; visualization: M.G.I., L.M.; supervision: M.G.I., L.M.; project administration: M.G.I.; funding acquisition: M.G.I. All authors have read and agreed to the published version of the manuscript.

Funding: This research was funded by University POLITEHNICA of Bucharest, grant number GNaC-ARUT 2018, identification code SU58-18-01, internal number 20730/15.10.2018. The APC was funded by University POLITEHNICA of Bucharest, through the previously mentioned project.

Acknowledgments: We are grateful to the students at University POLITEHNICA of Bucharest for the survey responses.

Conflicts of Interest: The authors declare no conflict of interest. The funders had no role in the design of the study; in the collection, analyses, or interpretation of data; in the writing of the manuscript, or in the decision to publish the results.

\section{Appendix A}

Table A1. Items associated with the four dimensions.

\begin{tabular}{|c|c|c|}
\hline Item No. & D1. & Professional Knowledge \\
\hline \multicolumn{3}{|c|}{$\begin{array}{l}\text { Picture yourself in the following situation: Starting from tomorrow, you are a teacher } \\
\text { in pre-university education, teaching a specialized discipline for which you are qualified. } \\
\text { To what extent do the following statements apply to you? Rate on a scale from } 1 \text { to } 5 \text {, } \\
\text { where } 1=\text { applies to me to a very small extent, } 5 \text { = applies to me to a great extent, and } \\
\text { follows the matrix. }\end{array}$} \\
\hline 1 & D1_1 & I know the scientific content of the discipline taught \\
\hline 2 & D1_2 & $\begin{array}{l}\text { I know which instructional strategies to use in my lessons in order to } \\
\text { achieve cognitive goals and to boost critical thinking, problem solving, } \\
\text { complex situations analysis and decision-making }\end{array}$ \\
\hline 3 & D1_3 & $\begin{array}{l}\text { I know the curricular documents that the teacher must use in their } \\
\text { teaching activity }\end{array}$ \\
\hline 4 & D1_4 & I am able to organize the scientific content in teaching sequences \\
\hline 5 & D1_5 & I am able to formulate the learning objectives of a lesson \\
\hline 6 & D1_6 & $\begin{array}{l}\text { I am able to imagine learning activities that will contribute to achieving } \\
\text { the learning goals and will foster transformative competences } \\
\text { (e.g., student agency, decision-making) }\end{array}$ \\
\hline 7 & D1_7 & $\begin{array}{l}\text { I know the students' learning styles and know how to adapt } \\
\text { the teaching strategy accordingly }\end{array}$ \\
\hline 8 & D1_8 & I know how to effectively use technology (ICT) in the teaching activity \\
\hline \multirow[t]{2}{*}{9} & D1_9 & $\begin{array}{l}\text { I know the students' age particularities and their influence on } \\
\text { the learning process }\end{array}$ \\
\hline & D2. & Professional Practice \\
\hline \multicolumn{3}{|c|}{ In the practice of your future teaching profession, you feel ready to: } \\
\hline 10 & D2_1 & Set learning goals to foster ESD pillars \\
\hline
\end{tabular}


Table A1. Cont.

\begin{tabular}{|c|c|c|}
\hline 11 & D2_2 & Plan the teaching process based on the curricular documents \\
\hline 12 & D2_3 & $\begin{array}{l}\text { Design the teaching activities taking into account the age particularities } \\
\text { of the students and how they can influence the learning }\end{array}$ \\
\hline 13 & D2_4 & $\begin{array}{l}\text { Apply different teaching strategies in order to integrate life skills } \\
\text { (e.g., decision-making, teamwork, conflict solving) }\end{array}$ \\
\hline 14 & D2_5 & $\begin{array}{l}\text { Integrate a wide range of resources into the teaching activity, including } \\
\text { ICT, in order to engage students in their own learning process and to } \\
\text { help them know themselves and others }\end{array}$ \\
\hline 15 & D2_6 & $\begin{array}{l}\text { Use different communication techniques to encourage students to get } \\
\text { involved in activities and work together effectively }\end{array}$ \\
\hline 16 & D2_7 & $\begin{array}{l}\text { Involve all the students in class activities (including those with special } \\
\text { educational needs) }\end{array}$ \\
\hline 17 & D2_8 & Manage classroom activities and set clear rules \\
\hline 18 & D2_9 & $\begin{array}{l}\text { Manage students' behavioural changes in order to help them to } \\
\text { self-regulate emotions and behaviours }\end{array}$ \\
\hline 19 & D2_10 & $\begin{array}{l}\text { Contribute to students' safety within the school, respecting } \\
\text { the law requirements }\end{array}$ \\
\hline 20 & D2_11 & $\begin{array}{l}\text { Use technology (ICT) in the teaching activities in a safe, responsible way, } \\
\text { respecting ethical norms and legislation }\end{array}$ \\
\hline 21 & D2_12 & $\begin{array}{l}\text { Apply different strategies for evaluating (formative and cumulative) } \\
\text { the students' results through which to verify the acquisition of all } \\
\text { the competences provided by the school syllabus }\end{array}$ \\
\hline 22 & D2_13 & $\begin{array}{l}\text { Build different assessment tools, with clear criteria and help compare } \\
\text { the learning outcomes of students }\end{array}$ \\
\hline 23 & D2_14 & $\begin{array}{l}\text { Provide adequate and timely (at the right time) feedback to the students } \\
\text { in order to boost their ability of learning to know and to learn }\end{array}$ \\
\hline 24 & D2_15 & Interpret the students' learning outcomes \\
\hline 25 & D2_16 & $\begin{array}{l}\text { Communicate the results of the assessment to the students so as to } \\
\text { encourage them to learn }\end{array}$ \\
\hline \multirow[t]{2}{*}{26} & D2_17 & $\begin{array}{l}\text { Assist students in self-assessment so as to make them aware of } \\
\text { their level. }\end{array}$ \\
\hline & D3 & Professional Engagement \\
\hline \multicolumn{3}{|c|}{ In the practice of your future teaching profession, you feel ready to: } \\
\hline 27 & D3_1 & Identify your own training needs \\
\hline 28 & D3_2 & $\begin{array}{l}\text { Establish a professional development plan to cover the identified } \\
\text { learning needs }\end{array}$ \\
\hline 29 & D3_3 & Develop/perfect your own learning strategies \\
\hline 30 & D3_4 & $\begin{array}{l}\text { Select appropriate information sources and resources in order to } \\
\text { develop professionally }\end{array}$ \\
\hline 31 & D3_5 & $\begin{array}{l}\text { Continuously improve yourself in order to improve the students' } \\
\text { learning process }\end{array}$ \\
\hline 32 & D3_6 & Ask for feedback from your colleagues to improve your teaching skills \\
\hline 33 & D3_7 & $\begin{array}{l}\text { Communicate effectively with the parents (regarding students' school } \\
\text { situation, keeping the confidentiality of results, solving certain } \\
\text { problems, etc.) }\end{array}$ \\
\hline 34 & D3_8 & Respect the ethics and conduct principles of the teaching profession \\
\hline 35 & D3_9 & $\begin{array}{l}\text { Respect the national legislation for the teaching profession, as well as } \\
\text { the regulations imposed by the school organization }\end{array}$ \\
\hline
\end{tabular}


Table A1. Cont.

\begin{tabular}{|c|c|c|}
\hline 36 & D3_10 & $\begin{array}{l}\text { Reflect upon the teaching practices (analysing and evaluating one's own } \\
\text { performance, student outcomes, etc.) to improve teaching strategies }\end{array}$ \\
\hline 37 & D3_11 & Respect the values of the school organization \\
\hline \multirow[t]{2}{*}{38} & D3_12 & $\begin{array}{l}\text { Get involved in various related activities, in order to contribute to } \\
\text { the development of the school }\end{array}$ \\
\hline & D4 & Self Management \\
\hline \multicolumn{3}{|c|}{ In the practice of your future teaching profession, you feel ready to: } \\
\hline 39 & D4_1 & Create a well-being atmosphere at school/in the activities \\
\hline 40 & D4_2 & $\begin{array}{l}\text { Effectively manage one's own activities (planning, organization, } \\
\text { responsibilities, etc.) }\end{array}$ \\
\hline 41 & D4_3 & Effectively manage one's own emotions in the activities \\
\hline 42 & D4_4 & Effectively manage the time allocated to the activities \\
\hline 43 & D4_5 & Self-motivate and self-discipline \\
\hline 44 & D4_6 & $\begin{array}{l}\text { Show flexibility and adaptability in the occurrence of changes } \\
\text { (new situations/working contexts, legislative changes) }\end{array}$ \\
\hline 45 & D4_7 & Make decisions related to the teaching career \\
\hline
\end{tabular}

\section{References}

1. Filho, L.W.; Raath, S.; Lazzarini, B.; Vargas, V.R.; de Souza, L.; Anholon, R.; Quelhas, O.L.; Haddad, R.; Klavins, M.; Orlovic, V.L. The role of transformation in learning and education for sustainability. J. Clean. Prod. 2018, 199, 286-295. [CrossRef]

2. Wolff, L.A.; Sjöblom, P.; Hofman-Bergholm, M.; Palmberg, I. High-performance education fails in Sustainability?-A reflection on finnish primary teacher education. Educ. Sci. 2017, 71, 32. [CrossRef]

3. Cebrián, G.; Junyent, M. Competencies in education for sustainable development: Exploring the student teachers' views. Sustainability 2015, 7, 2768-2786. [CrossRef]

4. Trott, C.D.; Weinberg, A.E.; Sample McMeeking, L.B. Prefiguring sustainability through participatory action research experiences for undergraduates: Reflections and recommendations for student development. Sustainability 2018, 10, 3332. [CrossRef]

5. Kioupi, V.; Voulvoulis, N. Education for sustainable development: A systemic framework for connecting the SDGs to educational outcomes. Sustainability 2019, 11, 6104. [CrossRef]

6. Balanay, R.; Halog, A. Teaching education for sustainable development at university level. In Teaching Education for Sustainable Development at University Level: A Case Study from the Philippines; Filho, L.W., Pace, P., Eds.; Springer: Berlin, Germany, 2016.

7. Dlouha, J.; Glavic, P.; Barton, A. Higher education in central European countries-Critical factors for sustainability transition. J. Clean. Prod. 2017, 151, 670-684. [CrossRef]

8. Bürgener, L.; Barth, M. Sustainability competencies in teacher education: Making teacher education count in everyday school practice. J. Clean. Prod. 2018, 174, 821-826. [CrossRef]

9. Pretorius, R.; Lombard, A.; Khotoo, A. Adding value to education for sustainability in Africa with inquiry-based approaches in open and distance learning. Int. J. Sustain. High. Educ. 2016, 17, 167-187. [CrossRef]

10. UNESCO. Education for Sustainable Development Goals: Learning Objectives; UNESCO (United Nations Educational, Scientific and Cultural Organization): Paris, France, 2017.

11. Darling-Hammond, L.; Newton, X.; Wei, R.C. Evaluating teacher education outcomes: A study of the stanford teacher education programme. J. Educ. Teach. 2010, 36, 369-388. [CrossRef]

12. Mohamed, Z.; Valcke, M.; de Wever, B. Are they ready to teach? Student teachers' readiness for the job with reference to teacher competence frameworks. J. Educ. Teach. 2016, 43, 151-170. [CrossRef]

13. Hanushek, E.A.; Piopiunik, M.; Wiederhold, S. The Value of Smarter Teachers: International Evidence on Teacher Cognitive Skills and Student Performance; No. 20727; National Bureau of Economic Research: Cambridge, MA, USA, 2014. 
14. Meroni, E.C.; Vera-Toscano, E.; Costa, P. Can low skill teachers make good students? Empirical evidence from PIAAC and PISA. J. Policy Model. 2015, 37, 308-323. [CrossRef]

15. European Commission. Education and Training. Monitor 2019. Romania; Publications Office of the European Union, Luxembourg: Brussels, Belgium, 2019.

16. Ávalos, B.; Valenzuela, J.P. Education for all and attrition/retention of new teachers: A trajectory study in Chile. Int. J. Educ. Dev. 2016, 49, 279-290. [CrossRef]

17. Kitchen, H.; Fordham, E.; Henderson, K.; Looney, A.; Maghnouj, S. OECD Reviews of Evaluation and Assessment in Education. Romania; OECD Publishing: Paris, France, 2017.

18. Popa, O.R.; Bucur, N.F. Teacher competences: Towards a definition framework. J. Pedagog. 2017, 1, $23-39$. [CrossRef]

19. Darling-Hammond, L. 'Teaching Is the Profession on Which All Other Professions Depend': Linda Darling-Hammond on Transforming Education; Stanford University: Stanford, CA, USA, 2018.

20. Kleinhenz, E.; Ingvarson, L. Standards for Teaching-Theoretical Underpinnings and Applications; New Zealand Teachers Council: Wellington, New Zealand, 2007.

21. Straková, Z. The perception of readiness for teaching profession: A case of pre-service trainees. J. Lang. Cult. Educ. 2015, 3, 32-42. [CrossRef]

22. Park, M.H.; Dimitrov, D.M.; Patterson, L.G.; Park, D.Y. Early childhood teachers beliefs about readiness for teaching science, technology, engineering, and mathematics. J. Early Child. Res. 2017, 15, 275-291. [CrossRef]

23. Fan, M.; Leung, L.P.; Hon, S.; Fan, K.L. Readiness of Hong Kong secondary school teachers for teaching cardiopulmonary resuscitation in schools: A questionnaire survey. Hong Kong J. Emerg. Med. 2019, 26, 174-178. [CrossRef]

24. Tschannen-Moran, M.; Hoy, A.W. Teacher efficacy: Capturing an elusive construct. Teach. Teach. Educ. 2001, 17, 783-805. [CrossRef]

25. UNESCO. Education for Sustainability from Rio to Johannesburg: Lessons Learnt from a Decade of Commitment; UNESCO (United Nations Educational, Scientific and Cultural Organization): Paris, France, 2002.

26. Ghorbani, S.; Jafari, S.E.; Sharifian, F. Learning to be: Teachers' competences and practical solutions: A step towards sustainable development. J. Teach. Educ. Sustain. 2018, 20, 20-45. [CrossRef]

27. Cambers, G.; Chapman, G.; Diamond, P.; Down, L.; Griffith, A.D.; Wiltshire, W. Teachers' Guide for Education for Sustainable Development in the Caribbean; UNESCO (United Nations Educational, Scientific and Cultural Organisation) Regional Bureau of Education for Latin America and the Caribbean OREALC: Santiago, Chile, 2008.

28. Mula, I.; Tilbury, D. A united nations decade of education for sustainable development (2005-14) what difference will it make? J. Educ. Sustain. Dev. 2009, 3, 87-97. [CrossRef]

29. Evans, L. Professionalism, professionality and the development of education professionals. Br. J. Educ. Stud. 2008, 56, 20-38. [CrossRef]

30. World Education Forum. Education for all: Meeting our collective commitments. In Proceedings of the World Education Forum 2000, Dakar, Senegal, 26-28 April 2000.

31. OECD. Supporting Teacher Professionalism: Insights from TALIS 2013; OECD: Paris, France, 2016.

32. Sexton, M. Evaluating teaching as a profession-Implications of a research study for the work of the teaching council. Ir. Educ. Stud. 2007, 26, 79-105. [CrossRef]

33. Wang, L.; Lai, M.; Lo, L.N. Teacher professionalism under the recent reform of performance pay in Mainland China. Prospects 2014, 44, 429-443. [CrossRef]

34. Danielson, C. Enhancing Professional Practice: A Framework for Teaching, 2nd ed.; Association for Supervision and Curriculum Development: Alexandria, VA, USA, 2007.

35. Sonmark, K.; Révai, N.; Gottschalk, F.; Deligiannidi, K.; Burns, T. Understanding Teachers' Pedagogical Knowledge: Report on an International Pilot Study; OECD Publishing: Paris, France, 2017.

36. Révai, N. What difference do standards make to educating teachers? In A Review with Case Studies on Australia, Estonia and Singapore; OECD Publishing: Paris, France, 2018.

37. AITSL. Australian Professional Standards for Teachers; Education Services Australia: Melbourne, Australia, 2014.

38. Education and Training Foundation. Initial Guidance for users of the Professional Standards for Teachers and Trainers in Education and Training-England; Education and Training Foundation: London, UK, 2014.

39. Andreson, S.K.; Terras, K.L.; Dagfinrud, M. Appraising teacher quality in Norwegian schools. Int. J. Bus. Humanit. Technol. 2013, 3, 16-42. 
40. Watt, H.M.G.; Richardson, P.W.; Wilkins, K. Profiles of professional engagement and career development aspirations among USA preservice teachers. J. Educ. Res. 2014, 65, 23-40. [CrossRef]

41. De Jesus, S.N.; Lens, W. An integrated model for the study of teacher motivation. Appl. Psychol. 2005, 54, 119-134. [CrossRef]

42. Sato, T.; Haegele, J.A. Physical educators' engagement in online adapted physical education graduate professional development. Prof. Dev. Educ. 2017, 44, 272-286. [CrossRef]

43. Toma, R.D. Self-management theory for developing teacher effectiveness: A new pedagogic approach to teacher effectiveness. Teach. Educ. 1992, 28, 27-33. [CrossRef]

44. Runhaar, P.; Bouwmans, M.; Vermeulen, M. Exploring teachers' career self-management. Considering the roles of organizational career management, occupational self-efficacy, and learning goal orientation. Hum. Resour. Dev. Int. 2019, 22, 368-384. [CrossRef]

45. Molías, L.M.; Ranilla, J.M.C.; Cervera, M.G. Pre-service physical education teachers' self-management ability: A training experience in 3D simulation environments. Retos Nuevas Tendencias en Educación Física Deporte y Recreación 2017, 32, 30-34.

46. Ngang, T.K.; Yunus, H.M.; Hashim, N.H. Soft skills integration in teaching professional training: Novice teachers' perspectives. In Proceedings of the 5th World Conference on Learning, Teaching and Educational Leadership, WCLTA 2014, Prague, Czech Republic, 29-30 October 2014.

47. National Authority for Qualifications (ANC). Available online: www.anc.edu.ro/standarde_app/SO/ Profesor\%20gimnaziu\%20-\%20liceu.pdf (accessed on 4 October 2019).

48. Nusrat, M.; Sultana, N. Soft skills for sustainable employment of business graduates of Bangladesh. High. Educ. Skills Work Based Learn. 2019, 9, 264-278. [CrossRef]

49. Akuegwu, B.A.; Edet, A.O.; Uchendu, C.C.; Ekpoh, U.I. Assessing teaching readiness of university students in Cross River State, Nigeria: Implications for managing teacher education reforms. High. Educ. Stud. 2011, 1, 96-102. [CrossRef]

50. Patton, M.Q. Qualitative Research E Evaluation Methods: Integrating Theory and Practice, 4th ed.; Sage: Thousand Oaks, CA, USA, 2015.

51. Eurostat. At Least upper Secondary Educational Attainment, Age Group 25-64 by Sex. Available online: https://ec.europa.eu/eurostat/databrowser/view/tps00065/default/table?lang=en (accessed on 4 October 2019).

52. Taber, K.S. The use of Cronbach's AlphaWhen developing and reporting research instruments in science education. Res. Sci. Educ. 2018, 48, 1273-1296. [CrossRef]

53. Herman, B.C. The influence of global warming science views and sociocultural factors on willingness to mitigate global warming. Sci. Educ. 2015, 99, 1-38. [CrossRef]

54. Tacq, J. Multivariate Analysis Techniques in Social Science Research: From Problem to Analysis; Sage Publications: Thousand Oaks, CA, USA, 1997.

55. Hooper, D.; Coughlan, J.; Mullen, M.R. Structural equation modelling: Guidelines for determining model fit. Electron. J. Bus. Res. Methods 2008, 6, 53-60.

56. MacCallum, R.C.; Browne, M.W.; Sugawara, H.M. Power analysis and determination of sample size for covariance structure modelling. Psychol. Methods 1996, 1, 130-149. [CrossRef]

57. Steiger, J.H. Understanding the limitations of global fit assessment in structural equation modeling. Personal. Individ. Differ. 2007, 42, 893-898. [CrossRef]

58. García, E.; Weiss, E. The Role of Early Career Supports, Continuous Professional Development, and Learning Communities in the Teacher Shortage; The Fifth Report in 'The Perfect Storm in the Teacher Labor Market' Series; Economic Policy Institute: Washington, DC, USA, 2019.

59. Bermejo-Toro, L.; Prieto-Ursúa, M.; Hernández, V. Towards a model of teacher well-being: Personal and job resources involved in teacher burnout and engagement. Educ. Psychol. 2016, 36, 481-501. [CrossRef]

60. Skaalvik, E.M.; Skaalvik, S. Job demands and job resources as predictors of teacher motivation and well-being. Soc. Psychol. Educ. 2018, 21, 1251-1275. [CrossRef]

61. Breitsohl, H. Beyond ANOVA: An Introduction to Structural Equation Models for Experimental Designs. Organ. Res. Methods 2019, 22, 649-677. [CrossRef]

62. Schwab, J. The teaching of science as enquiry. In The Teaching of Science; Schwab, J., Brandwein, P., Eds.; Harvard University Press: Cambridge, MA, USA, 1962.

63. Hill, H.C.; Rowan, B.; Ball, D.L. Effects of teachers' mathematical knowledge for teaching on student achievement. Am. Educ. Res. J. 2005, 42, 371-406. [CrossRef] 
64. McDiarmid, G.W. Teacher education: A vital part of the equity issue. State Educ. Lead. 1993, 12, 11.

65. Darling-Hammond, L.; Flook, L.; Cook-Harvey, C.; Barron, B.; Osher, D. Implications for educational practice of the science of learning and development. Appl. Dev. Sci. 2019, 1-44. [CrossRef]

66. Parsons, S.A.; Davis, S.G.; Scales, R.Q.; Williams, J.B.; Kear, K. How and why teachers adapt their literacy instruction. Mentor. Lit. Prof. 2010, 50, 221-236.

67. Vogt, F.; Rogalla, M. Developing adaptive teaching competency through coaching. Teach. Teach. Educ. 2009, 25, 1051-1060. [CrossRef]

68. Caena, F. Literature Review Teachers' Core Competences: Requirements and Development; Education and Training, 2020; European Commission: Brussels, Belgium, 2011.

69. UNICEF. The UNICEF Education Think Piece Series: Innovative Thinking for Complex Educational Challenges in the SDG4 Era; UNICEF: New York, NY, USA, 2015.

70. Darling-Hammond, L.; Hyler, M.E.; Gardner, M. Effective Teacher Professional Development; Learning Policy Institute: Palo Alto, CA, USA, 2017.

71. Liston, D.; Whitcomb, J.; Borko, L. Too little or too much: Teacher preparation and the first years of teaching. J. Teach. Educ. 2006, 57, 351-358. [CrossRef]

72. Romanian Presidency. Cariera Didactică. Rapoarte ale Grupurilor de Lucru [Teaching Career. Expert Group Reports]; Romanian Presidency: Bucharest, Romania, 2018.

73. Cochran-Smith, M.; Zeichner, K.M. Studying Teacher Education: The Report of the AERA Panel on Research and Teacher Education; Routledge: Abingdon, UK, 2009.

74. Zylfiu, H. Comparison of beginner and experience teachers. Educ. Sci. 2018, 14, 35-51. [CrossRef]

75. Beaudoin, K.M.; Mihić, S.S.; Lončarić, D. Croatian preschool teachers' self-perceived competence in managing the challenging behaviour of children. Cent. Educ. Policy Stud. J. 2018, 8, 123-138. [CrossRef]

76. Xu, Y.; Brown, G.T.L. Teacher assessment literacy in practice: Reconceptualization. Teach. Teach. Educ. 2016, 58, 149-162. [CrossRef]

77. Tang, K.N. The importance of soft skills acquisition by teachers in higher education institutions. Kasetsart J. Soc. Sci. 2018, 1-6. [CrossRef]

78. Botke, J.A.; Jansen, P.G.W.; Khapova, S.N.; Tims, M. Work factors influencing the transfer stages of soft skills training: A literature review. Educ. Res. Rev. 2018, 24, 130-147. [CrossRef] 